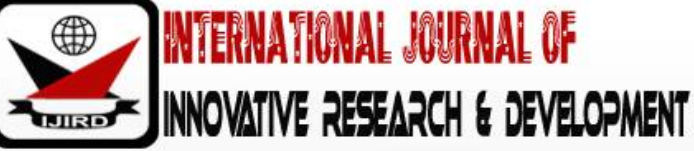

ISSN 2278 - 0211 (Online)

\section{Principal's Use of Mentoring Programmes on Prevalence of Drug and Substance Abuse in Public Secondary Schools in Busia County ,Kenya}

\begin{tabular}{c} 
Jeremiah Kalai \\
Associate Professor, Department of Education, University of Nairobi, Kenya \\
Lewis Ngesu \\
Associate Dean, Department of Foundations of Education, School of Education, \\
University of Nairobi, Kenya \\
Judith Mary Aguttu \\
Ph.D. Student, Educational Administration and Planninq, Universitv of Nairobi, Kenva \\
\hline
\end{tabular}

\begin{abstract}
:
The study sought to determine whether significant differences existed on levels of prevalence of drug and substance abuse among students in schools where principals supported mentoring education compared to those schools where principals did not support mentoring programmes. The study utilized descriptive survey design and the target population of students was 30,745. Out of a total of 30,745 students, a sample size of 420 students from 35 schools and 35 guidance and counseling teachers had questionnaires administered to them. Also35 principals responded to interview guides, and five education officers responded to a focused group discussion translating to 495 respondents. The statistical package for social sciences Software (SPSS) was used in the analysis. Levene's test for equality of variances and means was used for independent and dependent samples to determine whether significant differences existed between schools that supported mentoring education and their levels of drugs and substance abuse among the students. The study established that the schools which had mentoring programmes had lower reported cases of prevalence of drug and substance abuse compared to those schools which did not have mentoring programmes. The study established that the drug and substance are sneaked in by students from outside peddlers and finally the drug and substance are sneaked in by non-teaching staff. The study also established some measures that can be taken to control drug and substance abuse in public secondary schools are verbal warning, expelling students who abuse drug and substances, inviting parents to talk with their children on and lastly by arraigning in court the students who are caught abusing drugs and substances. The study concluded that mentoring programmes positively influenced student's behaviour in the sense that they reduced drug and substance abuse among students. The study recommends embracing of mentoring programmes in secondary schools where they were not yet embraced as a preventive measure for social vices including drug and substance abuse.

The study recommends that replication should be done in private secondary and primary schools in other parts of the republic where drugs are a menace, the Ministry of Education science and technology should include drug and substance education in the curriculum implementation, there should be drastic measures taken on students who are got abusing drug and substance.
\end{abstract}

Keywords: Student mentoring, student pairing, drug and substance abuse

\section{Introduction}

Drug and substance abuse among the youth is a major challenge facing the education sector. Globally it creates social-economic hardship, breeding misery which increase crime, violence and drain in all affected strata of the society. According to a survey conducted by the United Nations Office on Drugs and crime (UNODC, 2010), the war against drug abuse is far from over and drug barons are so powerful and ruthless that they are able to hold at ransom any one standing in their way of evil trade irrespective of one's position of authority. Countries like Peru, Bolivia and Columbia have large plantations of cocaine, while opium pappy a flower like plant from which heroin is produced glows illegally in Pakistan and Afghanistan (golden Crescent) and around Cambodia, Thailand and Laos (Golden Triangle), (United Nation Office on Drugs and Crimes, 2013).

Balding (2011) in a national survey conducted in England revealed that up to 53 percent of 14 to 15 years old are more likely to have been offered and taken drugs. The opium war of 1839 between Britain and China was triggered by drug trade.In 1992, the then UN Secretary General Boutros and Boutros Ghali lamented. The escalation in drug abuse among the youth and emphasized that the war against drug and substance abuse (DSA) should be fought by all nations 
(United Nations, 2000). The UN Secretary General called on all UN members states to enact drug trafficking laws that would significantly reduce the global illicit drug supply and demand (United Nations Office on Drugs and Crime, 2013).

In Africa, the drug problem is part of the larger social problem that affects sub-Saharan (African (SSA) Nations which have been transformed from transit points in an international drug network to consumer countries (Affinity, 2008). Three decades ago, in a workshop on alcoholism and drug addiction in Africa held in Nairobi Kenya, poverty, moral decadence and lack of good will among the leaders were found to be major hindrances to the fight against drug related crime in many African countries (Olatuwana \&Odejide, 2006). However, the situation is not different today as indicated by Odelide (2006). However, the situation is not different today as indicated by Odelide (2006) who further blamed inability to decisively deal with drug abuse in many African countries and schools on rampant corruption and involvement of organized cartels in drug trade.

The issue of drug abuse is therefore not new in our Kenyan public secondary schools but has only escalated. According to survey done by the big issue team, there is a general consensus that the problem of drug abuse and trafficking in schools is on the increase (East African Standard, January 19,2004). Another research done by the National Agency for the Campaign Against Drug Abuse (NACADA) shows that up to 92 percent of children aged between 16 to 26 are reported to have experimented with drugs, more than half of these stop using drugs after sometime but 25 percent continue abusing the substance (Maithya, 2009).

The role of the principal is to develop strategies through the mentoring programmes like use of teacher student sessions, lessons taught by the mentors, teachers carrying out guidance and counseling to students so as to reduce drug and substance abuse in schools and rewarding those who have stopped abusing drug and substance (Okumbe, 1999; Obiero, 2006). Through the secondary school curriculum, content on DSA is taught.

The general objective for teaching the Drug and Substance Abuse topic is to create awareness and deter the use of drugs by students (KIE, 2002, and 2008). Mentoring is also used in the fight against drug and substance abuse through pairing new students with senior students for guidance social support to address drug and substance abuse among students, students to discern right and wrong to address drug and substance abuse among students, encouraging students to be independent minded to address drug and substance among students, use pairing students with teachers for academic and social support to address drug and substance abuse among students, to invite professionals to provide career and social guidance to address drug and substance abuse among students and finally schools to invite former students to guide current students to address drug and substance abuse among students mentoring is far more than symbolic to create Drug and Substance Abuse awareness in schools (Matsigulu, 2006; Murangari, 2004).

In 2002, at Aid Round Table Forum in Salt Lake City, the then UN Secretary General, Koffi Annan stated that "mentoring can play a role in improving the lives of individuals and the whole community." He encouraged stakeholders to involve the youth in mentoring activities form early age to enhance responsibility and professionalism (United Nations Office on drugs and Crimes, 2011).

Guidance and counseling have been instrumental in the fight against Drug and Substance Abuse according to (Chand, 2008: Mungai 2007. Mungai (2007) further noted that individual counseling, group counseling, peer counselling, mentoring and the modelling are used to help students overcome drug abuse through counseling and mentoring students are taught the dangers of DSA and how to overcome peer pressure to smoke or drink (Botvin, 2000). Republic of Kenya (2008) indicates that principals and teachers are involved in prevention, control and mitigation of DSA through formal and non-formal programmes of mentoring. The study also emphasizes role modelling where students learn responsible behaviour from their teachers. Furthermore, the teachers' code of ethics and conduct prohibits smoking and drinking in the presence of students (Republic of Kenya, 2005).

Studies by Ng'ang'a (2003), Ngesu, Ndiku and Masese (2008) and Maithya (2009) established that mentoring programmes were useful in controlling onset of drug abuse among students and could also be used in the rehabilitation stage, the source of drug and substance were in three ways. The drug and substance are sneaked in by students, the students obtain the drugs from outside peddlers and finally they are sneaked in by non-teaching staff. The most common source is sneaking in by students and non-teaching staff.

The measures that can be taken to control drug and substance abuse in public secondary schools are: verbal warning on the students on drug and substance abuse, by expelling students who abuse drug and substance, by inviting parent $s$ to talk with their children on prevalence of drug and substance abuse and lastly by arraigning in court the students who are got abusing drug and substance Ng'ang'a (2007) recommended strategies that would combatively handle students in the drug abusing stage. Ngesu et al (2008) concluded that no one strategy could successfully curb drug abuse in a school environment. They concur that a combination approach that deals with awareness, prevention and intervention on abusers and follow up was the best way to deal with DSA in schools. It is for such reasons that this study has been conceived with an aim of suggesting the most appropriate strategy or combination of strategies that would work to curb DSA in different school categories.

\section{Statement of the Problem}

It is evident that drug and substance abuse is still a problem in our public secondary schools despite various measures taken to stop it. In the year 2008, many schools in Kenya were involved in strikes whereby they damaged school property as well as killing their colleagues. This was blamed on drug and substance abuse by the Ministry of Science and Technology. One is left to wonder whether it's just the mocks and big televisions which catalyzed them to do this or it is something else. It is possible that students who abuse drug and substance while in schools play a big role in influencing acts of indiscipline as they are under the influence of drugs. Thus, this study sought to find out the solution on prevalence of drug and substance abuse by using mentoring programmes as one of the principals' administrative practices among 
public secondary school students in Busia County. Therefore, the study investigated the use of mentoring programmes as one of the principals' administrative practices on prevalence of drug and substance abuse in public secondary schools in Busia County, Kenya.

The different forms of mentoring programmes used in the study are: pairing new students with senior students for guidance social support to address drug and substance abuse among students , students to discern right and wrong to address drug and substance abuse among students, encourage students to be independent minded to address drug and substance among students, pairing students with teachers for academic and social support to address drug and substance among students, inviting professionals to provide career and social guidance to address drug and substance abuse among students and finally to invite former students to guide current students to address drug and substance abuse among students.

The sources of drug and substance abuse were the students sneaking in drug and substance into the school, students obtaining the drugs from outside peddlers and finally they are sneaked in by non-teaching staff. The measures the previous studies outside the country recommended are: encouraging mentoring programmes as one-one relationship between the older adult and young person. The purpose of the relationship will be to provide guidance, provide abade ground for more sound judgement and establish friendship. Also mentoring and advocacy are widely used as promising mechanisms to provide substantial goal - directed support for students (Rew 2005 \& Lund 2002). There should also be parental engagement in substance abuse, depression, anxiety, learning difficulties and low self-esteem, all of which are beyond the scope of the mentoring programmes put in place by the schools to address the problem.

The measure that can be taken into consideration to control drug and substance within Kenya are verbal warming to the students, expelling students who abuse drug and substances by inviting parents to talk with their children on prevalence of drug and substance abuse and lastly by arraigning in court the students who are got abusing drug and substance. However, though all the mentioned measures are being taken into account, drug and substance abuse is still a big problem in public secondary schools and much effort is still needed both at the county and national levels so as to curb down the vice among the students.

\subsection{Purpose of the Study}

The purpose of the study was to investigate the use of mentoring programmes on prevalence of drug and substance abuse in public secondary schools in Busia County, Kenya.

\subsection{Objectives of the Study}

- To establish the influence of principal's use of mentoring programmes on prevalence of drug and substance abuse in public secondary schools in Busia County, Kenya.

- To identify the source of drug and substances in public secondary schools in Busia County, Kenya.

- To establish the measures that can be taken to control drug and substance abuse in public secondary schools in Busia County, Kenya.

\section{Theoretical Framework}

The study is based on the social resistance skills theory as proposed by Gilbert Botvin (2010).The social resistance skills theory argues that social and psychological factors are central in promoting the onset of cigarette smoking and latter, drug and alcohol abuse. The social resistance theory holds that drug abuse result from pro-drug social influences from peers, persuasive advertising appeals and media portrayals encouraging drug use, along with exposure to drug-using role models. The causes of drug abuse cited in this study, centre on some of the above psychosocial factors. Based on this theory, principals need to adopt, secondary indication in the environment (including not only physical aspect of the environment but also the addicts life style) is associated with the primary stimuli of the addict's drug experience resistance skills programmes as a whole have generally been successful in the U.K. A comprehensive review of resistance skills studies published from 1980 to 1990 reported that the majority of prevention studies (63 percent) had positive effects on drug use behavior, with or negative effects on behavior (11 percent) (Botvin, 2000).

The most popular school-based drug education programme basedon the social influence theory is Drug Abuse Resistance Education or project (DARE).The limitations of the social resistance skills approach are that it assumes that young people do not want to use drugs but lack the skills or confidence to refuse. For some youth, however, using drugs may not be a matter of yielding to peer-pressure but may have instrumental value; it may for example help them deal with anxiety, low self-esteem or lack of comfort in social situations. For some, use of drugs especially alcohol makes them feel grown-ups. The theory also assumes that if youths are not exposed to drugs, drug using role models and pro-drug social influences, then they are unlikely to become drug abusers. The theory applies to the study in that it prohibits young people from pro-drug influences from peers, persuasive advertising appeals and media portrayals encouraging drug use. 


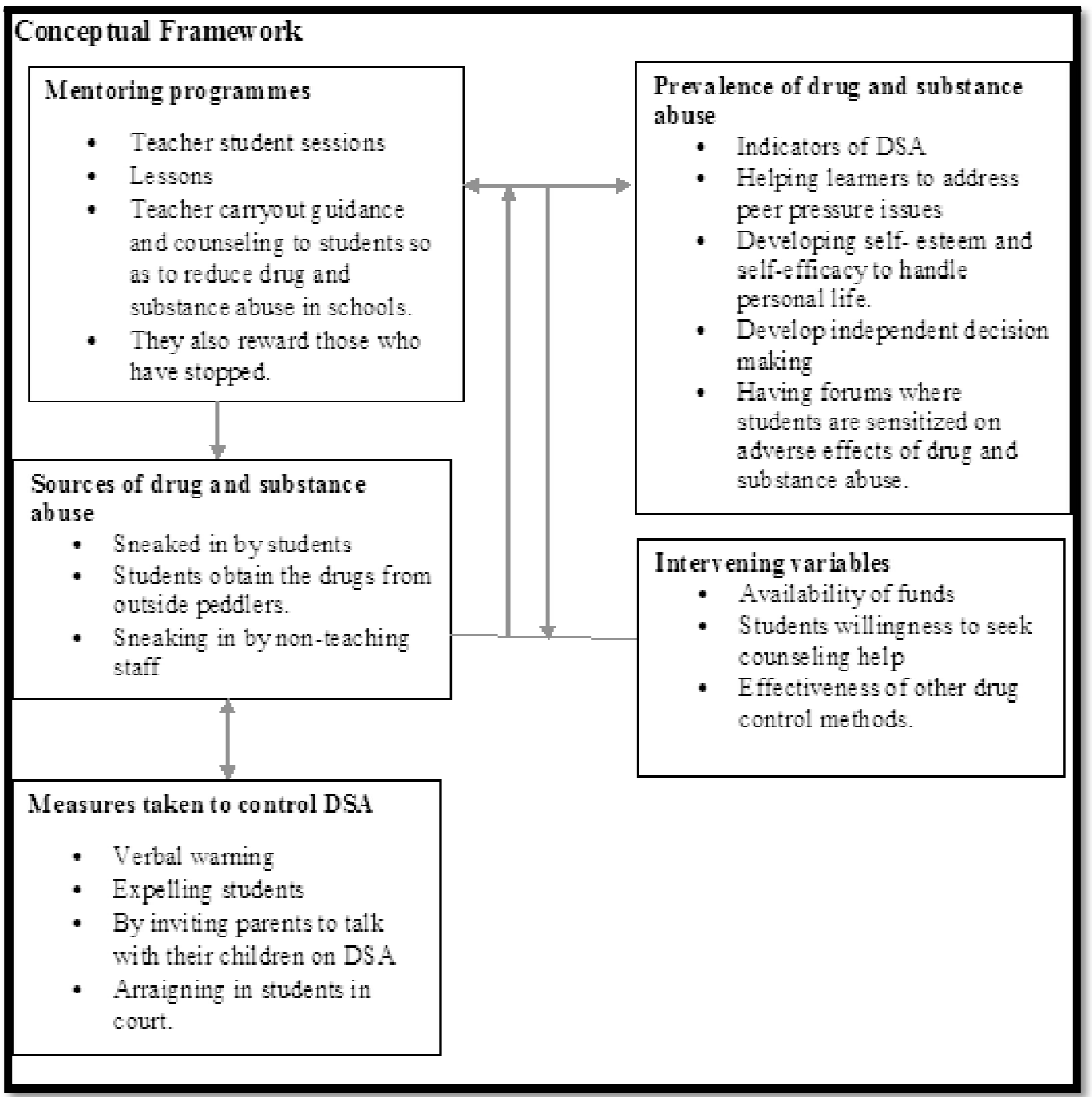

Figure 1: Mentoring Programmes and Drug and Substance Abuse among Students

The conceptual framework is a concise description of the phenomenon under study accompanied by a graphic depiction of the major variables of the study (Mugenda, 2008). It is the perspective or the set of lenses through which the researcher views the problem. It conceptualizes the interrelationships between the two study variables, in this case, principals' practices used curb DSA (independent variable) and prevalence of drug and substance abuse in schools (dependent variable) as shown in figure 1.

The conceptual framework shows mentoring programmes in curbing DSA among students. In this study, the level of DSA is conceptualized as an outcome of principals' administrative strategies. The principals' characteristics and the school category influence the strategies used to create awareness and shape the students' behaviours. School rules play to deter abuse of drugs and substance. NACADA involved in initiating intervention programmes enacting and enforcing drug trafficking laws, teaching moral values to students and reporting cases of traffickers and abusers within the context of the DSA mitigation process so that the use of Drug and Substance Abuse in schools is reduced.

\subsection{Research Design}

Descriptive survey design was used to obtain information from various departments. Orodho and Kombo(2003) described descriptive survey as a method of collecting information by interviewing or administering a questionnaire to a sample of individuals. It can be used when collecting information about peoples' attitudes, opinions, habits or any of the variety of education or social issues (Orodho\&Kombo, 2003).

\subsection{Target Population}

Mugenda and Mugenda (2003) defined a sampling frame as a list, directing on index of cases selected. According to list obtained from the County Director of Education office (2013), Busia County had 68 public secondary schools, 19 boys, 20 girls and 29 mixed schools. The population for the students was 30,745.Out of 30745, 420 students were sampled for the study. All the 68 principals, 68 heads of guidance and counselling and all the 420 students formed the target population of the study.

\subsection{Sample Size and Sampling Procedures}

Best and Kahn (2010) define a sample as a small proportion selected for observation and analysis. Fifty percent of the schools, principals, heads of guidance and counselling department and 50 percent of the students were used as 
recommended by Mugenda, (2008). Stratified sampling was used to classify schools into; girls only, boys only and mixed schools, mainly because single gender schools are fine with different experiences or the problem of drug abuse hence adopt different strategies to curb the problem compared to mixed schools as observed by (Imbosa, 2009). The summary of the target population and sample size of the school type is shown in table 1.

\begin{tabular}{|c|c|c|c|c|c|c|c|c|}
\hline $\begin{array}{c}\text { School } \\
\text { Type }\end{array}$ & $\begin{array}{c}\text { Target } \\
\text { Pop }\end{array}$ & $\begin{array}{c}\text { Sample } \\
\text { Size }\end{array}$ & $\begin{array}{c}\text { Head } \\
\text { Teacher }\end{array}$ & $\begin{array}{c}\text { HOD } \\
\text { G\&C }\end{array}$ & $\begin{array}{c}\text { Form } \\
\mathbf{1}\end{array}$ & $\begin{array}{c}\text { Form } \\
\mathbf{2}\end{array}$ & Form 3 & Form 4 \\
\hline Boys & 19 & 10 & 10 & 10 & 30 & 30 & 30 & 30 \\
\hline Girls & 20 & 10 & 10 & 10 & 30 & 30 & 30 & 30 \\
\hline Mixed & 29 & 15 & 15 & 15 & 45 & 45 & 45 & 45 \\
\hline Total & 68 & 35 & 35 & 35 & 105 & 105 & 105 & 105 \\
\hline
\end{tabular}

Table 1: Sample Size per School Type

$n=p \% \times q \% \times\left({ }_{e}^{z} \%\right) 2$ i.e. $7 \% 72$, where $\mathrm{n}$ is the minimum sample size required if the target population is greater than 1000. P\% is the proportion in the target population estimated to have the characteristic (assume $5 \%$ if unknown). $\mathrm{Q} \%$ the proportion estimated not to have the characteristic (l-p) $\mathrm{z}$ is the standard normal deviation at the required confidence level $\mathrm{e} \%$ is the level of statistical significance. Substituted as;

$50 \times 50 \times[1.96 / 5] 2=2500 \times(0.392) 2-2500 \times 0.154=385$

385 students.

Selection of students; to calculate the sample of students, the formula provided by Sounders, Lewis and Thornwill (2007); and Mugenda (2008) was used. The formula was preferred because it gave a fair presentation of students per class and gender.

Selection of principals: after selecting 50 percent of schools in the county, all the principals of the selected schools were used in the study using stratified proportionate sampling; hence a total of 35 principals, selection of H.O.D Guidance and Counseling; All the heads of guidance and counseling departments in the 35 selected schools were included in the study by stratified proportionate sampling because they are responsible for guiding students and counseling those with Drug and Substance Abuse problems in schools.

The table shows the study population and the sample of schools, principals, H.O.D's guidance and counseling and students as per their class. Selection of schools; simple random sampling was used to select 50 percent of each type; giving a total of 10 boys' schools, 10 girls' school and 15 mixed school. There were two national schools which were purposively included in the study, that is, one boys' school and one girls' school. The study noted there is no mixed national school in Busia County.

The study used 420 students in line with the target population of Mugenda and Mugenda (2003) as a sampling frame list directing on index cases selected. Since the population was 30,745 at least 420 was a quarter of the population which is recommended for any good study.

\subsection{Instrument for Data Collection}

The researcher used questionnaire for students, questionnaire for guidance and counseling, interview guide for principals and group discussion with officials from education office. The questionnaire was preferred overall the others because it normally takes less time to construct and was cheaper to administer according to Mugenda and Mugenda (2003). It also gives no room for irrelevant information as is the case with other instruments like interviews (Mugenda \& Mugenda, 2003). The questionnaires were divided into objectives. There was a questionnaire for students, questionnaire for guidance and counseling teacher's andan interview guide for the principals and focusedGroup Discussions guide for education Officers.

\subsection{Valid1ity of Research Instrument}

Five questionnaires were distributed to five research experts at University of Nairobi. The responses received in the questionnaires were analyzed in terms of content validity, which addresses the extent to which the questionnaire provides adequate coverage of the topic provided under study. The interview guide was conducted for the principals and was analysed. This ensured that the data obtained from questionnaire was meaningful and accurate. The group discussion was also analyzed and presented in the way it is supposed to be. The researcher incorporated in the instrument's inputs from experienced researchers and graduate research supervision, the discipline of Educational administration, through their advice, more items were modified or omitted completely to improve the validity of instruments. However, the overall aim was to improve instrument items and gather the intended data.

\subsection{Reliability of Research Instrument}

Reliability refers to the extent to which the measure is without bias or results is consistent overtime, was done using the test -retest reliability method. This was used because of ease of accessibility and availability of the participants. The five questionnaires were re-administered to the experts after two weeks. A test -retest method was used to determine reliability of the interviewer schedule. This involved administering the instruments first group with similar characteristics to survey or research settings then the instrument items were improved depending on extent to which the items were suitable to gather the required information when instruments were administered in the main study. This method ensured that the instrument gathered relatively the same information obtained in the first test when administered in the main 
study. This is due to the fact that ambiguous difficulty and unclear items were either simplified or discarded altogether or new items added to instruments depending on the outcome of the first test.

\subsection{Data Collection Procedures}

The researcher started data collection after seeking and obtaining a research permit from National Commission of Science, Technology and Innovation (NACOSTI) to conduct research from the various public secondary schools in Busia County. The researcher then contacted the County Director of Education to be allowed to carry out the research in the county. The researcher also contacted the County Commissioner to be allowed to carry out research in the county. The sampled schools were visited and the principal informed about the study was explained to the respondents. The questionnaires were self, administered to students, guidance and counselling teachers who were the respondents. Thereafter, the interview schedule was used on principals after explaining to them the purpose of the study. Also, the focused group discussion was conducted with County Education Officers adequately. There were five County Education officials who participated in the study. These were County Director of Education, (Teachers Management), County Director of Education, County Quality Assurance, County Human Resource and Sub-County Director of Education.

\subsection{Data Analysis Techniques}

The data collected was organized, tabulated and analyzed using descriptive and inferential statistics, frequencies and percentages were used and presentation was done using graphs as summary. The computer programme on statistical package for social sciences (SPSS) was used to assist in data analysis. Analysis of data was important in explaining the variables of the study. The data from the interview scheduled for the principals was analyzed using a descriptive statistic.

Comparison of schools where principals conduct mentoring programmes versus those which do not conduct in relation to prevalence of drug and substance abuse was carried out. Percentages and frequencies of prevalence of drug and substance abuse were carried out on this mentoring programmes. A t. test was done to determine whether significant differences existed in drug and substance abuse among students where principals conducted student mentoring programmes and where they did not.

\subsection{Findings and discussions on Principals' use of mentoring programmes and prevalence of drug and substance abuse}

Mentoring refer to a relationship between a teacher and a student meant to Provide professional and social support to the mentee by the mentor. The Guidance and counseling teachers are used as mentors in schools on prevalence ofdrug and substance abuse among students. In this case the guidance and counseling teachers are supposed to provide professional and social guidance to Students on prevalence of drug and substance abuse. The guidance and counseling teachers should help in curbing down drug and substance abuse in schools among students. The guidance and counseling teachers use the following methods tocurb down drug and substance in schools among students.

\begin{tabular}{|c|c|c|c|}
\hline Statement & Response & Frequency & Percent \\
\hline $\begin{array}{l}\text { i. Does your school use pairing new } \\
\text { students with senior student for guidance } \\
\text { social support to address drug and substance } \\
\text { abuse among students? }\end{array}$ & $\begin{array}{l}\text { Yes } \\
\text { No } \\
\text { total }\end{array}$ & $\begin{array}{l}127 \\
274 \\
401\end{array}$ & $\begin{array}{l}31.7 \\
68.3 \\
100\end{array}$ \\
\hline $\begin{array}{l}\text { ii. Does your school use teaching } \\
\text { students to discern right and wrong to } \\
\text { address drug and substance abuse among } \\
\text { students? }\end{array}$ & $\begin{array}{l}\text { Yes } \\
\text { No } \\
\text { total }\end{array}$ & $\begin{array}{l}221 \\
180 \\
401\end{array}$ & $\begin{array}{l}55.1 \\
44.9 \\
100\end{array}$ \\
\hline $\begin{array}{l}\text { iii. Does your school encourage } \\
\text { students to be independent minded to } \\
\text { address drug and substance among students? }\end{array}$ & $\begin{array}{l}\text { Yes } \\
\text { No } \\
\text { total }\end{array}$ & $\begin{array}{l}214 \\
187 \\
401\end{array}$ & $\begin{array}{l}53.4 \\
46.6 \\
100\end{array}$ \\
\hline $\begin{array}{l}\text { iv. Does your school use pairing } \\
\text { students with teachers for academic and } \\
\text { social support to address drug and substance } \\
\text { among students? }\end{array}$ & $\begin{array}{l}\text { Yes } \\
\text { No } \\
\text { total }\end{array}$ & $\begin{array}{c}79 \\
322 \\
401\end{array}$ & $\begin{array}{l}19.7 \\
80.3 \\
100\end{array}$ \\
\hline $\begin{array}{l}\text { v. Does your school invite } \\
\text { professionals to provide career and social } \\
\text { guidance to address drug and substance } \\
\text { abuse among students? }\end{array}$ & $\begin{array}{l}\text { Yes } \\
\text { No } \\
\text { total }\end{array}$ & $\begin{array}{l}109 \\
292 \\
401\end{array}$ & $\begin{array}{l}39.4 \\
60.6 \\
100\end{array}$ \\
\hline $\begin{array}{l}\text { vi. Does your school invite former } \\
\text { students to guide current students to address } \\
\text { drug and substance abuse among students? }\end{array}$ & $\begin{array}{l}\text { Yes } \\
\text { No } \\
\text { total }\end{array}$ & $\begin{array}{c}89 \\
312 \\
401\end{array}$ & $\begin{array}{l}22.2 \\
77.8 \\
100\end{array}$ \\
\hline
\end{tabular}

Table 2: Forms of Mentoring Programmes to Address Drug and Substance Abuse

From the table the most commonly used mentoring programme activities to address drug and substance abuse where teaching students to discern right at $51.1 \%$ by encouraging students to be independent minded with 53.4 percent. The finding could be informed by the fact that teaching to discern right and wrong is done on daily basis and could be used to discourage the drug and substance abuse in schools. Encouraging students to be independent minded is a rather innovative approach since it is likely to capture attention of young students in schools. The schools which use mentoring 
programs and most specially to discern right and wrong, followed by discouraging students to be independent included, have higher levels on prevalence of drug and substance abuse compared to those schools which do not practice the mentoring programs.

\begin{tabular}{|c|c|c|}
\hline Method & Frequency & Percent \\
\hline Verbal warning & 16 & 46 \\
\hline Expulsion & 5 & 14 \\
\hline Inviting parents & 6 & 17 \\
\hline Arraigned in court & 8 & 23 \\
\hline Total & 35 & 100 \\
\hline
\end{tabular}

Table 3: Methods Used by Guidance and Counseling Teachers to Discourage Drug and Substance Abuse among Students in Schools

Table shows that verbal warning to students, expulsion of students, inviting parents of students, and arraigning students in courts are the methods used by guidance and counseling teachers to discourage drug and substance abuse among students in schools. This study found out that the guidance and counseling teachers are most used in schools on mentoring programmes, the focused group discussion of education officers concurred with the use of mentoring programmes in schools.

\begin{tabular}{|c|c|c|c|c|c|}
\hline & $\begin{array}{c}\text { Providing Professionals } \\
\text { to Provide Career And } \\
\text { Social Support }\end{array}$ & F & Mean & $\begin{array}{c}\text { Standard } \\
\text { Deviation } \\
\text { On }\end{array}$ & $\begin{array}{c}\text { Standard } \\
\text { Error }\end{array}$ \\
\hline $\begin{array}{c}\text { Do you have } \\
\text { schoolmates who } \\
\text { abuse drugs? }\end{array}$ & YES & 158 & 0.04050 & 0.23251 & 0.01850 \\
\cline { 2 - 6 } & NO & 243 & 0.04050 & & 0.00818 \\
\hline
\end{tabular}

Table 4: T.Test on Group Statistics of Inviting Professionals

Table shows that 158 respondents acknowledged having professionals to provide career and social guidance on drug and substance abuse at 39.4 percent while 243 did not acknowledge inviting professionals to provide career and social guidance at 60.6 percent. The standard deviation was got of the students who acknowledged the invitation of professionals to provide career and social guidance being 0.23251 and those who did not acknowledge got 0.2750 . This shows there is significant difference in using the method of mentoring on prevalence on drug and substance abuse.

The group standard error difference of students who acknowledged the use of inviting professionals to provide career and social guidance was 0.01850 and the non-acknowledgement was 0.00818 the figures shows that there is a significant difference because they are all less than0.05. Any figure less than 0.05 is taken to be significant.

The mean is 0.04050 which means that schools carrying out mentoring programs have higher levels on prevalence of drug and substance abuse compared to those schools which do not have mentoring programs.

\begin{tabular}{|c|c|c|c|c|}
\hline & & \multicolumn{2}{|c|}{$\begin{array}{c}\text { Levene's Test for } \\
\text { Equality of Variances }\end{array}$} & $\begin{array}{c}\text { T Test for Equality } \\
\text { of Means }\end{array}$ \\
\cline { 3 - 5 } & F & Sig & T \\
\hline $\begin{array}{c}\text { Do you have } \\
\text { schoolmates who } \\
\text { abuse drugs }\end{array}$ & $\begin{array}{c}\text { Equal variances } \\
\text { assumed }\end{array}$ & 20.807 & .000 & 2.240 \\
\cline { 2 - 5 } & $\begin{array}{c}\text { Equal variances } \\
\text { not assumed }\end{array}$ & 20.807 & & 2.003 \\
\hline
\end{tabular}

Table 5: Levene's Test for Equality of Variances

The table shows t. test shows variances and equality of means. It also shows the equal variances assumed which is $\mathrm{f} 20.807$. This means that all the variances are taken into consideration. $t$ test for equality of means assumed is 2.240 and not assumed is 2.003. Since the significance difference is 0.000 this means that the schools which have mentoring programs have higher levels of prevalence of drug and substance abuse compared to those schools which do not use the method. Also, because the significance is 0.000 , any number below 0.05 is meant to be significant therefore the use of mentoring programs is significant on prevalence of drug and substance. 


\begin{tabular}{|c|c|c|c|c|}
\hline & & \multicolumn{3}{|c|}{ T. test for Equality of Means } \\
\hline & & df & Sig (2 tailed) & Mean difference \\
\hline $\begin{array}{c}\text { Do you have } \\
\text { school mates } \\
\text { who abuse drugs }\end{array}$ & $\begin{array}{c}\text { Equal variances } \\
\text { assumed }\end{array}$ & 399 & -025 & .04050 \\
\cline { 2 - 5 } & $\begin{array}{c}\text { Equal variances } \\
\text { not assumed }\end{array}$ & 216.968 & -046 & .04050 \\
\hline
\end{tabular}

Table 6: Independent test (2-tailed) and the Mean Difference

The table shows $t$ test for equality of means assumed is 0.2240 and not assumed is 0.2003 . The $t$ test also brought out a significance of 2 tailed meaning more than two items or two items are being tested. Therefore the sig. of 2 tailed was -025 for equal variances assumed and the mean difference of equal variance assumed was 0.04050 . While the sig. ( 2 tailed) equal variance was - 046 and the mean difference of equal variance not assumed was 0.04050 . This means the significance difference of -0.46 is less than 0.05 and this shows that there was a significance difference on using mentoring programmes on prevalence of drugs and substance abuse. The significance is -0.25 for equal variances assumed and -0.46 for equal variances not assumed. This shows that since the figures are less than 0.05 there is a significant difference which exist between the schools which use mentoring programs as a means to curb down drug and substance abuse compared to those schools which do not use the method. Therefore, this shows that the schools which use mentoring programs hence higher levels of prevalence of drug and substance abuse compared to those schools which do not use the method.

\begin{tabular}{|c|c|c|c|}
\hline & $\begin{array}{c}\text { t-test for equality means } 95 \% \\
\text { confidence interval of the } \\
\text { differences }\end{array}$ & \\
\hline & & Lower & Upper \\
\hline \multirow{2}{*}{$\begin{array}{l}\text { Do you have } \\
\text { schoolmates who } \\
\text { abuse drugs }\end{array}$} & $\begin{array}{l}\text { Equal variances } \\
\text { assumed }\end{array}$ & .00505 & .07595 \\
\hline & $\begin{array}{c}\text { Equal variances } \\
\text { not assumed }\end{array}$ & .00064 & .08036 \\
\hline
\end{tabular}

Table 7: T. Test for Confidence Interval of the Difference

The table shows t test for equality of means 95percent confidence interval of the differences was calculated. The equal variance assumed was 0.0505 on lower side and upper was 0.7595 was received. The equal variances not assumed of lower was 0.00064 and 0.080036 at upper side. All the $t$ test fall under less than 0.05 . This means that the mentoring programmes using the methods given by students are very significant in public secondary schools on the prevalence of drug and substance abuse.

There is a significant difference which exists between levels on prevalence of drug and substance abuse in schools where principals support mentoring programmes versus those which do not support mentoring programmes. Those schools which have mentoring programmes have higher levels on prevalence of drug and substance abuse compared to those schools which do not practice the exercise.

Comparing the current study to the previous study of mentoring and advocacy, it is widely used as promising mechanisms to provide sustained goal directed support for student (row 2005 and row 2002). Mentors are therefore very important in school because they help in guiding students on how to avoid drug and substance abuse in order to achieve better performance.

\subsection{The Identification of Source of Drug and Substance}

There are three sources where the students get drug and substance. The drug and substance are sneaked in by students, the students obtain the drugs from outside peddlers and finally they are sneaked in by non-teaching staff. The most common sources are sneaking in by students with a frequency of 240 out of 401 at 59.9 percent followed by sneaking in by non-teaching staff having 121 out of 401 with a percentage of 30.2. Only 40 students out of 401 responded that they also obtain drug and substance from the outside peddlers at 9.9 percent, totaling to 100 percent.

Measures that can be taken to control drug and substance abuse in public secondary schools in Busia County in Kenya. Respondents who were mostly guidance and counseling teachers with 75 percent stated that the following were the measures taken into consideration on controlling of drug and substance abuse.

By verbal warning on the students on drug and substance abuse, by expelling students who abuse drug and substance by inviting parents to talk with their children on prevalence of drug and substance abuse and lastly by arraigning in court the students who are got abusing drug and substance while 25 percent of the respondents believed that this is also contributed by the students willingness to accept the measures put in place in schools on control over drug and substance abuse. The principals and the focus group discussion officers who were educationists concurred with the measures.

\section{Conclusion}

This study concludes that use of mentoring positively reduces incidences of drug and substance abuse among students. 


\section{Recommendation}

- Mentoring programmes should be embraced in schools where they were not yet embraced as a preventive measure for social vices including drug and substance abuse.

- The schools should ensure that there should be control on the sources of drug and substance abuse to students through searches.

- The schools should establish strong measures that can be taken into account so as to control drug and substance abuse.

- The study should be carried out in private secondary schools and primary schools in other parts of the republic where drugs are a menace.

\section{Suggestions for Further Research}

- Mentoring programmes should be carried out also in urban setup because the study was carried out in rural areas.

- The school should establish strong measures that can be taken into account so as to control drug and substance abuse.

- The Ministry of Science and Technology should set up strong measures that can control drug and substance abuse.

\section{References}

i. Balding, J. (2011). Trends: young people and illegal drugs. Attitudes to and experience of illegal drugs 1987-2004. Exeter: schools health education unit.

ii. Best and Kahn (2010). Sample as a small proportion selected for observation and analysis.

iii. Bleeker, (2012). Peer Education as a Process of Sharing Information.

iv. Borg, R.W. \& Gall, (1996). Educational research. (6th ed.) New York: Longman Inc.

v. Botvin, G. J. (2010). "Preventing drug abuse in schools: social and Competence enhancement approaches targeting individual-level etiological factors." addictive behaviours 25, 887 - 897.

vi. Carnigie, D. Turner \& Shinner, (1999). Drug Abuse in the Republic of Ireland: An Overview, Bulletin onNarcotics. 38 (1-2): 91-97.

vii. Chand, S. (2008). Guidance and counselling (For teachers, parents andstudents). New Delhi: S. Chand and company Ltd.

viii. Chandler, R. K., Fletcher, B. W., \&Volkow, N. D. (2009). Treating drugabuse and addiction in the criminal justice system: improving public health and safety. Jama, 301(2), 183-190.

ix. Darcis, J. (2004). Youth in Peril. Alcohol and drug abuse in Kenya. Nairobi: Baseline survey.

x. Etinberger, K. W., Runyon, R. P \& Haber, A. (1990). Fundamentals of socialstatistics. (2nd ed.) New York: McGrawHill,Inc.

xi. Imbosa, M. (2009). An Investigation into Strategies Used in Addressing Drug Abuse Problems: A Case Study of Nairobi Provincial Boys' Secondary Schools. A Master of Education Research Project Report, Kenyatta University.

xii. KIE, 2002, and 2008.A topic on awareness and deterring the use of drugs by students

xiii. Khanyisile, T. (2010). Evaluation of Primary Prevention of Substance AbuseProgramme amongst Young People at Tembiso. Master of Arts Dissertation: Faculty of Arts. University of Johannesburg: South Africa.

xiv. Lewis N. M.\& Thornwill (2007). Formulae provided for presentation of the sample size per class and gender.

xv. Maithya, R. W. (2009). Drug abuse in secondary schools in Kenya: Developing a programme for prevention and intervention. Doctor of Education in socio-Education, University of South Africa.

xvi. Matsigulu, M. M. (2006). The role of the Kenya music festival in eradicating Drug and Substance Abuse in public secondary schools in Kikuyudivision Kiambu District, Kenya. Unpublished Master of Education Project. University of Nairobi.

xvii. Mugenda, A. G. (2008). Social Science Research: Theory and principles. Nairobi: Applied Research and Training Services.

xviii. Mugenda,O. M. \& Mugenda A.G. (2003). Sampling Frame as a List, directing or index of cases selected.

xix. Mungai, J. G. (2007). The role of head teachers in promoting drug abuse counselling among students in public secondary schools in Nyeri and Mbeere Districts. A PhD Thesis, Kenyatta University.

xx. Muranguri, C. W. (2004). The role of drama in Eradicating Drug and Substance Abuse in secondary schools in Starehe and Kamukunji divisions. Unpublished M.Ed. project.

xxi. Ng'ang'a, R. M. (2007) and Poipoi (1998). A study of participatory approaches used by the Head teachers to control drug abuse in public secondary schools in Nyeri District. UnpublishedM. Ed Thesis. University of Nairobi

xxii. Ngesu, L. M., Ndiku, J. \& Masese, A. (2008). Drug dependence and abuse inKenyan secondary schools: strategies for intervention. Educational research and reviewvol.3 (10), pp304-308.http:/ / www. academic journals.org/ EPR.

xxiii. United Nations Office on drugs and Crimes, 2011enhancing responsibility and professionalism Obiero, J. A. (2006). The Effect of the administrative practice on Kenya

xxiv. Certificate of Primary Education performance in Maseno Division Kisumu District. Unpublished M.Ed research project, University of Nairobi.

xxv. Orodho, J.A. \& Kombo, D.K. (2003). Descriptive Survey Methods on Education and Social Issues.

xxvi. Okumbe, J. A. (2001). Human Resource Management. An Educational Perspective. Nairobi: Educational development and research bureau. 